\title{
An Eviction in Kinnitty: Republican Social Agitation and the New Fianna Fáil Government, 1932-1933
}

Timothy O'Neill

\section{(2) OpenEdition \\ Journals}

\section{Electronic version}

URL: http://journals.openedition.org/etudesirlandaises/3776

DOI: $10.4000 /$ etudesirlandaises.3776

ISSN: 2259-8863

\section{Publisher}

Presses universitaires de Rennes

\section{Printed version}

Date of publication: 30 June 2014

Number of pages: $105-117$

ISBN: 978-2-7535-3449-0

ISSN: 0183-973X

\section{Electronic reference}

Timothy O'Neill, «An Eviction in Kinnitty: Republican Social Agitation and the New Fianna Fáil Government, 1932-1933 », Études irlandaises [Online], 39-1 | 2014, Online since 30 June 2016, connection on 19 April 2019. URL : http://journals.openedition.org/etudesirlandaises/3776; DOI : 10.4000/etudesirlandaises.3776 


\title{
An Eviction in Kinnitty: Republican Social Agitation and the New Fianna Fáil Government, 1932-1933
}

\author{
Timothy O’NeILL \\ Central Michigan University
}

Abstract

This article uses an eviction in Co. Offaly to examine the interaction between national and local republican politics during the first year of Fianna Fáil in power. These politics revolved around and revealed the internal tensions within the IRA as it attempted to develop a strategy to counter the new Government, and that Government's attempt to consolidate state power, which necessitated resisting the desire among local republicans to settle ten-year old local scores from the Irish Civil War, while simultaneously consolidating the republican base at the expense of the IRA.

Keywords: Irish republicanism; land question; political parties; IRA

\section{Résumé}

Cet article prend l'exemple d'une expulsion dans le comté d'Offaly pour étudier les interactions entre les politiques locales et nationales des républicains lors de la première année au pouvoir de Fianna Fáil. Ces politiques révèlent les tensions internes au sein de l'IRA, qui cherchait alors à mettre en place une stratégie de résistance au nouveau gouvernement. Elles montrent également la volonté du gouvernement d'affermir le pouvoir de l'État - ce qui avait pour conséquence de ne pas céder au désir des militants locaux de solder dix années de querelles locales issues de la guerre civile tout en consolidant le soutien républicain dont il pouvait bénéficier au détriment de l'IRA.

Mots clés : Républicanisme irlandais; question agraire; partis politiques; IRA

On the morning of July 19, 1932 a bailiff approached the Craven home in Kinnitty, Co. Offaly to serve a routine eviction notice. His first indication that this was not to be a routine eviction was probably when he saw the 1916 Easter Proclamation nailed to the door with an attached statement which in part read: "If a change of Government means a continued freedom for the bailiff-vulture and the house-wreckers, well, then, goodbye to liberty. No tribute to Britain ${ }^{1}$." More problematic for the bailiff and the new Fianna Fáil Government was that the home was also occupied by thirty-five men of the local IRA unit who told the

1. Irish Independent, 20 July 1932, 7. 
bailiff they would not surrender the house. The Kinnitty Fianna Fáil Club not only supported the IRA's actions to prevent the eviction, it demanded that their two Fianna Fáil TDs return from Dublin to join the agitation and called upon the new Fianna Fáil Minister for Justice to stay the eviction ${ }^{2}$. Four months earlier Eamon de Valera and his Fianna Fáil party had been brought to power on the electoral strength of the local Fianna Fáil Clubs and local IRA units, which, at the local level in places such as Kinnitty, often shared a common membership ${ }^{3}$.

On the surface, the Kinnitty eviction appeared to represent a socially radical republican base directly challenging the government it had recently elected. Internal IRA and Fianna documents, however, reveal a somewhat more complex story of the Kinnitty eviction, that is, a story of internal politics within the IRA and Fianna Fáil. This article will use the eviction in Kinnitty to examine the interaction between national and local republican politics. These politics revolved around the internal tensions within the IRA as it attempted to develop a strategy to counter the new Fianna Fáil Government, and that Government's attempt to consolidate state power, which necessitated resisting the nearly universal desire among local republicans to settle ten-year old local scores from the Irish Civil War, while simultaneously consolidating the republican base at the expense of the IRA.

Before examining the eviction in Kinnitty, however, some historical context is required. During the late 1920s and early 1930s the IRA leadership divided over the question of strategy. A group of social, or left, republicans within the IRA leadership, led by Peadar O'Donnell, argued that the IRA needed to lead the masses in social agitation which would in turn launch a social revolution and smash the Free State. O'Donnell attempted to use the issue of land annuities, which the Cosgrave Government continued to collect and pass on to Britain, as the means to rally the masses. Fianna Fáil, however, successfully transformed the anti-Annuities Campaign, and its revolutionary potential, into an electoral issue and rode the issue to power in $1932^{4}$. Militarists within the IRA leadership opposed using the Army for social agitation. Tom Barry often spoke for this group, arguing that social agitation was mere politics, which was beneath the IRA, and that the IRA needed to focus on rebuilding the Army's military capabilities and preparing for the day when it would be in a position to resume the Civil War.

The task of balancing these two views within the leadership rested with Moss Twomey, the IRA's leader. Twomey himself was a revolutionary socialist and

2. Irish Press, 20 July 1932, 1.

3. For larger treatment of the IRA during this period see: Brian Hanley, The IRA 1926-1936 (Dublin), 2002; for Fianna Fáil, see: Richard Dunphy, The Making of Fianna Fail Power in Ireland, 1923-1948 (Oxford, 1995).

4. See: Timothy M. O’Neil, "Handing away the Trump Card? Peadar O'Donnell, Fianna Fáil and the NonPayment of Land Annuities Campaign, 1926-1932", New Hibernia Review, 12, 1 (Spring 2008), p. 19-41. 
further to the left than most social republicans ${ }^{5}$, but preserving Army unity took precedence over his own politics. Twomey believed that the IRA was the Irish Republic and as such Army unity was paramount: "I'm if you like a fanatic in this matter [unity] - that I believe nothing in the country matters to Republicanism but the IRA." Against the protests of the militarists within the IRA leadership, Twomey permitted the Army to move toward Left politics, but refused to establish an IRA political organization, which the social republicans within the IRA leadership desired. Nonetheless, during the late 1920s the IRA affiliated with the Communist International in Moscow and joined with Irish communists in establishing numerous Comintern front organizations in Ireland ${ }^{7}$. Such moves, however, failed to satisfy the social republicans who continued to agitate for an open IRA political organization. At the 1931 Army Convention, Twomey brokered a compromise that permitted the social republicans to launch an IRA - sponsored political program known as Saor Eire (Free Ireland).

By 1931 the Free State began to buckle under the pressure of a general republican resurgence and the global economic crisis. In October, the Cosgrave Government responded to this threat with a two-pronged offensive. First, it secured a pastoral from the Church hierarchy that denounced Saor Eire and by implication the IRA as communistic, and then by enacting legislation that gave it the same emergency powers as those it had enjoyed during the Civil War. The attack against the IRA forced its leadership on the run while the Free State rounded up and imprisoned rank-and-file Volunteers. Coinciding with its offensive against the IRA, the Cosgrave Government called a snap election and attempted to portray its parliamentary opposition, that is, its Civil War republican opponents de Valera and Fianna Fáil, as part of the communist conspiracy. Although many within the IRA leadership retained their deep suspicion of politics in general, and de Valera in particular, the government offensive forced a change in IRA electoral policy. In January 1932, the IRA leadership suspended a previous order that had prohibited Volunteers from either working for campaigns of from voting for candidates for the "illegal Free State Assembly". The following month, with the important electoral support of the IRA and the land annuities issue, de Valera and Fianna Fáil won the election and assumed state power.

Upon entering office, de Valera ordered the release of all IRA prisoners and withheld the land annuities payments to Britain, while still collecting them from Irish farmers and retaining them for the Free State. Britain responded with a tariff

5. Uinseann MacEoin, The IRA in the Twilight, Years, 1923-1948, (Dublin: Argenta, 1997), 843.

6. Letter from Moss Twomey to Frank Ryan, 3 March 1933, P69/185/53/177, Moss Twomey Papers University College Dublin Archives, henceforth cited as UCDA P69.

7. For a discussion of the IRA and the Comintern see: Emmet O'Connor, "Jim Larkin and the Communist Internationals, 1923-9”, Irish Historical Studies XXXI No. 123 (May 1999), p. 357-372. 
on Irish goods and thus began the Economic War. While Fianna Fáil's actions proved wildly popular with the republican base, de Valera did not, of course, reproclaim the Republic, which placed the IRA in a difficult position; as Twomey put it: "Nobody had visualised a Free State which Republicans were not suppose to attack ${ }^{8}$." De Valera's position towards the IRA was that once Fianna Fáil had retained the land annuities and removed the Oath of Allegiance to the British Crown, the IRA needed to accept the principle of majority rule, hand over its arms and give allegiance to the Free State ${ }^{9}$. Needless to say, anything short of rerestablishing the Irish Republic was unacceptable to the IRA.

A week after Fianna Fáil assumed power, the IRA leadership produced an internal document which asked and answered two essential questions: 1) can Fianna Fáil's methods and policies achieve the Republic, to which it answered no, and 2) can the IRA launch a successful revolution against the Fianna Fáil Government, to which it also answered no, placing the IRA's dilemma in sharp focus. What then was to be done? The document reasonably concluded that the new situation required a political response and asked, but did not answer, the question: should the IRA use its military capacity in domestic issues such as supporting workers in strikes or preventing the eviction of small farmers ${ }^{10}$ ? Answering that question, of course, was bound to once again divide the social republicans and the militarists within the IRA leadership.

In May 1932, Tom Barry informed Twomey that he could no longer accept the IRA's social program, Saor Eire, explaining: "the Army is a body with a moral right to make war and kill when necessary to achieve this country's freedom, but I cannot accept the right of any organisation to make war to make effective their social programme against the wishes of the majority of the people ${ }^{11}$." Barry added that any social program made it difficult for a person of his mentality to go all out for the Army ${ }^{12}$. Twomey replied to Barry that the IRA needed to organize the people behind the Army and to achieve that objective, a social program was essential, adding that the IRA social program did indeed represent the views of the vast majority of the Irish people ${ }^{13}$. Two months later, Barry again wrote Twomey to inform him that he and de Valera had held a two-hour meeting to discuss republican unity and during that meeting de Valera had offered to create a new national defense organization which would include the IRA ${ }^{14}$. Barry told Twomey that he was very much impressed by the offer and the IRA leadership should consider it.

\footnotetext{
8. Memorandum for IRA Envoy to Clan na nGael, 25 August 1932, UCDA P69/185/221.

9. IRA Memo, no title, 23 March1932, UCDA P69/53/377.

10. Ibid.

11. Letter from Tom Barry to Moss Twomey, 13 May 1932, UCDA P69/52/63.

12. Ibid.

13. Copy of letter from Moss Twomey to Tom Barry, 24 May 1932, UCDA P69/52/62.

14. IRA, Confidential Report of Tom Barry's meeting with Fianna Fáil, 17 July 1932, UCDA P69/52/55.
} 
Twomey rejected the idea out of hand and believed that he had convinced Barry that advocating the IRA's co-option into the Free State was a very bad idea ${ }^{15}$. What remained unclear to Twomey regarding the Fianna Fáil-Barry meetings was the extent to which Barry was freelancing or representing the militarists in the IRA leadership. Given Barry's impulsiveness and narcissism, Twomey believed it was the former ${ }^{16}$.

It was in the midst of dealing with Barry's unauthorized rapprochement with Fianna Fáil that Twomey learned that Seán McGuinness, a social republican within the IRA leadership, had deployed Volunteers of the Offaly Battalion to prevent the eviction in Kinnitty. McGuinness had an impressive republican service record and was the stalwart of the IRA in Offaly during the Civil War ${ }^{17}$. He had a long history of social agitation and in 1924 wrote a memo to the IRA leadership arguing that the republican movement needed to be reconstructed on the issue of land agitation and redistribution. His memo also pointed out that in his area, the Irish Land Commission was only giving land to the supporters of the Cosgrave Government, that is members of the Cumann na nGaedheal political party ${ }^{18}$. McGuinness was elected as a republican TD for Leix-Offaly in 1923, only to be given the distinction in 1925 of being the only republican TD ever stripped of their seat, which resulted from his conviction for physically assaulting a member of the Garda Síochána ${ }^{19}$. He was sentenced to 18 months' hard labor but escaped and went to America ${ }^{20}$. By 1930 he had returned to Ireland, resumed his republican activities, and was elected to the Saor Eire executive only to be re-imprisoned in April 1931. When released by the Fianna Fáil Government in March 1932, McGuinness addressed a victory celebration to welcome home republican prisoners in Dublin's College Green, telling the crowd that the members of the former Cosgrave Government were "a menace to society and the independence of Ireland, and it behooved all Republicans to unite and wipe that menace out at all costs ${ }^{21}$."

In May 1932 McGuinness sought Army Council authorization for his plan to prevent government land seizures for the nonpayment of land annuities ${ }^{22}$. To have authorized such a plan, of course, meant challenging Fianna Fáil. Given the general republican euphoria over the election of Fianna Fáil and the popularity of the policy to retain the land annuities, Twomey believed that at this juncture it

15. Ibid.

16. Letter from Moss Twomey to IRA O/C Cork No. 1 Brigade, 19 July 1932, UCDA P69/157/32/54.

17. Philip McConway, "The Civil War in Offaly", Tribune (Clara, Co. Offaly), 2 January 2008, 1.

18. Memo from IRA O/C Leix, 8 January 1924, UCDA P69/144/89.

19. Irish Independent, 30 October 1931, p. 8.

20. Ibid., 10 August 1929, p. 11.

21. Irish Times, 14 March 1932, p. 1.

22. Copy of letter from IRA A/G to IRA O/C Offaly Battalion, 19 May 1932, UCDA P69/157/32. 
was dangerous to even criticize Fianna Fáil ${ }^{23}$. McGuinness and other social republicans, however, disagreed with Twomey and wanted the IRA to confront Fianna Fáil by demanding a moratorium on the payment of annuities by farmers to the Free State. Twomey contended that as long as Fianna Fáil was fighting the British for retention of annuities, the IRA should not "complicate the issue by advocating a 'no rent' campaign ${ }^{24}$." The Army Council responded to McGuinness' request by reminding him that he attended the meeting of the executive where his plan was discussed at length and rejected and then reproached him for continuing to advocated such a policy in the Labour paper Workers Voice after it had been rejected by his comrades on the IRA executive ${ }^{25}$.

Explicitly denied Army Council permission to prevent government land seizures for the nonpayment of annuities, McGuinness decided to challenge Fianna Fáil by preventing the eviction of 76-year-old Patrick Craven and his family in Kinnitty. Craven had lived in the gate house of the Biddulph estate for 19 years where he worked as the caretaker. The Land Commission took control of the estate and sold it to Captain Joseph Nugent, an ex-Free State Army officer. Nugent now sought the eviction of the Craven family from the gatehouse which was located on the roads which led to Nugent's mansion ${ }^{26}$. McGuinness had warned Nugent not to proceed with the eviction ${ }^{27}$, while the president of the Kinnitty Fianna Fáil Club, Sean's brother Patrick McGuinness ${ }^{28}$, had wired both the Minister for Lands and the Minister for Justice demanding that they to stop the eviction in Kinnitty. He received no reply ${ }^{29}$.

When Sean McGuinness learned that the eviction was to take place on morning of July 19, he dispatched Volunteers of the IRA's Offaly Battalion to occupy and barricade the home in order to prevent the eviction ${ }^{30}$. Patrick McGuinness wired both of Offaly's Fianna Fáil TDs, Patrick Boland and Patrick Gorry, demanding that they come to Kinnitty immediately and join the protest ${ }^{31}$. Both Boland and Gorry did arrive that morning, but not to join the agitation. Boland visited nearby Fianna Fáil Clubs and attempted to persuade them not to become involved in the Kinnitty agitation, arguing that the eviction was not the business of the Fianna Fáil organization ${ }^{32}$. He told a meeting of a nearby Fianna Fáil Club in Tullamore, that the Government was "up against bigger things than

23. Copy of letter from Moss Twomey to G.N. Count Plunkett, 9 April 1932, UCDA P69/52/239.

24. Memorandum for IRA Envoy to Clan na nGael, 25 August 1932, UCDA P69/185/221.

25. Copy of letter from IRA A/G to IRA O/C Offaly Battalion, 19 May 1932, UCDA P69/157/32.

26. Irish Times, 23 July 1932, p. 12.

27. Letter from Sean McGuiness to IRA A/G, 20 July 1932, UCDA P69/158/251.

28. Irish Independent, 8 January 1927, p. 8.

29. Internal IRA Report "A Kinnitty Eviction", July 1932, UCDA P69/158/243.

30. Letter from Sean McGuiness to IRA A/G, 20 July 1932, UCDA P69/158/251.

31. Internal IRA Report "A Kinnitty Eviction", July 1932, UCDA P69/158/243.

32. Irish Times, 20 July 1932, p. 5. 
an eviction ${ }^{33}$." The implication of the "bigger things" was confronting the British in the Economic War and their "imperialist agents" in Ireland - Cumann na nGaedheal. Minister of Justice Geoghegan replied to Patrick McGuinness that he had no power to stay the eviction ${ }^{34}$. TD Patrick Gorry meet with Sean McGuinness at the Craven home and told him that the land belonged to Nugent, but that he had the sheriff agree to stay the eviction for two days so that he could negotiate with Nugent ${ }^{35}$. With this assurance, Sean McGuinness agreed to have the IRA temporarily vacate the house. Gorry returned to Dublin and meet with the Minister of Justice who, according to Gorry, assured him that the eviction would not take place. The following morning, however, the Craven family was evicted and sent to the poor house ${ }^{36}$.

Moss Twomey was less than pleased with the events in Kinnitty. Not only had McGuinness acted without consulting the Army Council, his decision to withdraw the IRA from the house permitted Craven's eviction and thus had embarrassed the IRA and damaged its reputation. Twomey asked McGuinness why he had trusted a Fianna Fáil TD and pointed out the obvious: Gorry had "deliberately misled you ${ }^{37 ”}$. Regarding Twomey's contention that his actions had damaged IRA's reputation, McGuinness disagreed and argued that Craven's eviction had shown the people that there was no difference between Fianna Fáil and the Cosgrave government and the countryside was now with the IRA ${ }^{38}$. McGuinness launched a boycott against Captain Nugent and planned to hold weekly Sunday demonstrations until Craven was reinstated. He wanted Twomey to send speakers from Dublin for the agitation, especially Peadar O'Donnell - the greatest agitator of his generation ${ }^{39}$. Twomey denied the request, telling McGuinness that it sounded like the agitation had a good following and it would be more effective if the speakers were local men, not men from Dublin ${ }^{40}$.

Peadar O'Donnell, of course, found his way to Kinnitty and he and the McGuinness brothers led the agitation. Sean McGuinness told a protest meeting that "in evicting Craven the Government has issued a direct challenge to the people, and this challenge the people are prepared to meet ${ }^{41}$." While Patrick McGuinness condemned the Fianna Fáil government, the other speakers, who were mostly other Fianna Fáil club presidents or county councilors, had no inten-

33. Brian Hanley, The IRA 1926-1936, p. 140.

34. Irish Independent, 20 July 1932, p. 7.

35. Letter from Sean McGuiness to IRA A/G, 20 July 1932, UCDA P69/158/251.

36. Internal IRA Report “A Kinnitty Eviction”, July 1932, UCDA P69/158/243.

37. Memo RE: Kinnitty Eviction from Moss Twomey to IRA O/C Offaly Battalion, 27 July 1932, UCDA P69/158/245.

38. Letter from Sean McGuiness to IRA A/G, 25 July 1932, UCDA P69/158/246.

39. Ibid.

40. Copy of memo from IRA A/G to IRA O/C Offaly Battalion, 28 July 1932, UCDA P69/158/243.

41. Irish Times, 23 July 1932, p. 7. 
tion of challenging the Fianna Fáil Government. In fact, most of the local republican speakers refused to even criticize the Fianna Fáil Government. According to James Garvin of the Co. Offaly Council, "he did not come here to criticize the Fianna Fáil Government. He was a 'wholehogger' for its policy but if there was a law which permitted the eviction of Craven and his family it should be changed ${ }^{42}$." John Finn, another Fianna Fáil county councilor, went even further, explaining that "the law which permitted the eviction had not been made by the present government. This government has been obstructed and has not got a chance to work ${ }^{43}$ ". Such statements, of course, conflicted with Sean McGuinness' reports to the Army Council that the eviction had shown the people of Offaly that there was no difference between Fianna Fáil and the Cosgrave government. Indeed, nearly all of the local republican speakers dissociated the eviction from the Fianna Fáil Government, instead focusing on Joseph Nugent, the man who had evicted the Cravens, denouncing him as the ex Free State Army officer who had been rewarded by Cumann na nGaedheal for his treason against the Irish Republic - a man, as it was frequently mentioned, who was from the County Clare $^{44}$. This inference, perhaps, was that Nugent was not native to Offaly and therefore in addition to his treason, he was a "land grabber" who had no ancestral right to the land.

According to newspaper accounts, the demonstrations in Kinnitty drew large crowds from surrounding counties but failed to reinstate the Craven family. The demonstrations did, however, raise enough money to build a wooden hut for the Cravens, with a kitchen and two rooms, on property near their former home ${ }^{45}$. During the agitation, Twomey repeatedly asked McGuinness on what terms did Craven hold the house and what was the reason for his eviction ${ }^{46}$. McGuinness never answered those questions and it appears that Craven had no legal right to the house. It also appears that the attempt to prevent the eviction and the agitation that followed had far more to do with his evictor, Captain Nugent, than with Craven's claim to the house, or even Craven himself. As McGuinness put it, "Craven - an old man - was never much of an asset to the independence movement. It was not so much in his favour [we acted] as it was to get a crack at Nugent and the system he represents ${ }^{47}$ ". It was also rumored that Nugent had executed republican prisoners during the Civil War. The IRA's C/O for East Clare,

\footnotetext{
42. Ibid., 26 July 1932, 5.

43. Ibid.

44. Irish Times, 23 July 1932, p. 12

45. Irish Independent, 1 August 1932, p. 10.

46. Memo RE: Kinnitty Eviction from Moss Twomey to IRA O/C Offaly Battalion, 27 July 1932, UCDA P69/158/245.

47. Letter from Sean McGuiness to IRA A/G, 20 July 1932, UCDA P69/158/251.
} 
however, could not confirm that accusation, only that while drunk Nugent had beaten and threatened to shoot republican prisoners during the Civil War ${ }^{48}$.

The statement that McGuinness nailed to the door of the Craven home described the evictor as: "A ex-Free State Army Captain named Joe Nugent, who was presented with a large farm and mansion thereon by the Cosgrave Murder gang for service rendered with the King's Irish mercenaries during the 1922-3 struggle that was created by the British with a backing renegade and traitor Irishmen ${ }^{49}$." While Craven appears to have held no legal claim to the property, in the minds of the McGuinness brothers and many local republicans in Kinnitty, Nugent's claim to the property was based on his treason to the Irish Republic. As Sean McGuinness put it, they were acting against "Nugent and the system he repre$\operatorname{sents}^{50}$ ". That system was translated at the local level with the material rewards of state power as the victors of the Civil War, Cumann na nGaedheal, used the Irish Land Commission to reward its supporters with land. Indeed, under the Cosgrave Government it was rare for someone to receive land if he was not a member of a local Cumann na nGaedheal Club ${ }^{51}$.

All politics is local, of course, and in Ireland even more so. Offaly had long been contested space between Republicans and the supporters of Cumann na nGaedheal. The five-seat constituency of Leix-Offaly repeatedly split between the anti-Treaty and pro-Treaty parties with Labour taking the fifth seat. It had been the home constituency of Kevin O'Higgins, the man in the Cosgrave Government whom republicans detested the most and held mainly responsible for the execution of Republican prisoners during the Civil War and considered the strongman behind the Cosgrave Government. After his unauthorized assassination by members of the IRA in 1927, his brother Thomas O'Higgins took one of the Cumann na nGaedheal seats in Leix-Offaly. Thomas O'Higgins founded the Blueshirts, Ireland's proto-fascist movement, and in doing so cited the IRA's prevention of the Kinnitty eviction as one of the reasons why such a movement was necessary ${ }^{52}$.

Twomey's strategy to counter Fianna Fáil did not rest with land agitation, because he believed de Valera, unlike the Cosgrave government, would use the resources of the state to purchase the agitators. In Twomey's words, "Fianna Fáil can buy off most of the farmers who are agitating today; they are in a position to make concessions, including moratoriums s $^{53}$." Twomey's position on land agita-

48. Copy of memo from IRA D/I to IRA O/C Offaly Battalion, 28 July 1932, UCDA P69/158/244.

49. Copy of proclamation of those occupying Craven house, ca. 19 July 1932, UCDA P69/158/257.

50. Letter from Sean McGuinness to IRA A/G, 20 July 1932, UCDA P69/158/251.

51. Terence Dooley, "Land and politics in independent Ireland, 1923-1948: the case for reappraisal", Irish Historical Studies, XXXIV, no 134 (november 2004), p. 185.

52. Meath Chronicle, 27 August 1932, 8.

53. Letter from Moss Twomey to Sean Lennon, 6 August 1932, UCDA P69/52/2. 
tion during this period is best illustrated by his response to contemporary events in Co. Tipperary, where local republicans reported that "as a result of the failure to divide the land and give it to Republicans [...] a very strong anti-Fianna Fáil feeling has developed ${ }^{54}$." This report, of course, mirrored McGuinness's reports from Kinnitty. Volunteer Ned O'Reilly argued that these aggrieved republicans would join the IRA if it established an organization to lead the agitation ${ }^{55}$. The IRA's Tipperary O/C, however, did not share O'Reilly's opinion ${ }^{56}$. Twomey was cautious believing that such agitation could be seen as anti-Fianna Fáil, and asserted: "Our [IRA] position is that while we cannot very well put ourselves at the head of the agitation for the distribution of land, we certainly should not oppose it. On the contrary we should do everything we can to have as many of our people as possible fixed up ${ }^{57}$." When ex-Volunteers, who were also members of Fianna Fáil, launched such an organization and claimed to have done so to support the IRA, the IRA put an end to it, telling them that while the IRA had no objections to local agitation on the part of active Volunteers or ex-Volunteers to secure land, it would not tolerate the formation of an organization to conduct the agitation ${ }^{58}$.

While Twomey rejected land agitation as the IRA's strategy to counter Fianna Fáil, he clearly was "in favour of Volunteers, and even ex-Volunteers, getting jobs and land in preference to the enemies of the Republic $c^{59}$." This was a ten-year old objective of all republicans. He warned, however, that Fianna Fáil would give a preference to ex-Volunteers, not active Volunteers and that de Valera would use land distribution in his effort to co-opt active Volunteers into the Free State ${ }^{60}$. Thus, Twomey's opposition to agrarian agitation, in addition to his fears that it would divide the IRA leadership, was also rooted in his fear that Fianna Fáil would use its state power to numerically weaken the IRA with the reward of land. His response to the agitation in Tipperary, although no IRA units were involved as was the case in Kinnitty, is instructive. He once again demonstrated his aversion to directly challenging Fianna Fáil, which he believed would be seen by the republican base as weakening Fianna Fáil and by implication assisting the "Cosgrave Murder Gang." During this period, the IRA outlined its position regarding Fianna Fáil in a dispatch to the United States: "We cannot afford to be put in a

54. Letter from Moss Twomey to Jack Jones, 1 October 1932, UCDA P69/54/34.

55. Ibid.

56. Ibid.

57. Ibid.

58. Letter from IRA A/G to O/C Limerick City Battalion, 18 October 1932, UCDA P69/54/34.

59. Letter from Moss Twomey to O/C Limerick City Battalion, 14 December 1932, UCDA P69/54/28.

60. Ibid. 
position of appearing to help the Imperialists [Cumann na nGaedheal], or of weakening Fianna Fáil against them ${ }^{61}$."

Rank-and-file Fianna Fáil TDs, behind closed doors, challenged their Government's position regarding the IRA, land distribution and its failure to punish their Civil War enemies. The Minutes of the Fianna Fáil Parliamentary Party reveal that many of the party's supporters and backbenchers wanted the supporters of Cumann na nGaedheal punished and republicans rewarded - especially IRA Volunteers. During a weekly meeting of Fianna Fáil TDs in July of 1932, John Flynn moved to give IRA men preference on public works, but withdrew his motion on the instance of de Valera who asserted that Volunteers would receive "all possible consideration ${ }^{62}$ ". Even though Fianna Fáil had secured an absolute majority in the January 1933 General Election, many TDs contended that the majority would have been even larger if it was not for the Land Commission's unjust treatment of local republicans in the distribution of land ${ }^{63}$. As such, "a complete revolution of the Land Commission was demanded and that special attention should be given to the IRA in the distribution of land ${ }^{64}$. De Valera rejected this demand, as well as demands to establish a tribunal to try individuals for crimes against republicans during the Civil War, by arguing for "the necessity of closing finally the chapter of the Civil War in Ireland ${ }^{65 "}$. While de Valera successfully resisted demands from his republican base to settle ten-year old scores against their Civil War enemies, he was forced to accept the principle that his Government needed to consult the party before enacting policy that would change the "economic outlook" of the Fianna Fáil movement ${ }^{66}$. When Fianna Fáil consolidated state power, the Land Commission became an instrument to reward loyal party supporters with land, just as Cumann na nGaedheal had used it to reward its supporters ${ }^{67}$. De Valera used state employment, pensions and land distribution to convert active Volunteers into ex-Volunteers, just as Twomey had warned. Republican Marie Comerford later described such largess as "Fianna Fáil bribery ${ }^{68}$.

Even though de Valera and his Fianna Fáil Government resisted the demands from the republican base to punish individual members of Cumann na nGaedheal, their retention of the land annuities and the ensuing Economic

61. Army Council Dispatch No. 198 to Clan [na Gael], 15 September 1932, UCDA P69/185

62. Minutes of the Fianna Fail Parliamentary Party, 14 July 1932, Records of the Fianna Fail Party (P176) 444, UCDA.

63. Ibid., 30 March 1933.

64. Ibid., 6 April 1933.

65. Ibid.

66. Ibid.

67. Terence Dooley, "Land and politics in independent Ireland, 1923-1948: the case for reappraisal", Irish Historical Studies, XXXIV, n 134 (November 2004), p. 185.

68. Uinseann MacEoin, Survivors, (Dublin, Argenta, 1980), p. 32. 
War and protectionism exacted a collective punishment as the price of cattle was nearly cut in half between 1932 and $1935^{69}$. This reduction hit large ranchers the hardest, that is to say, the supporters of Cumann na nGaedheal. When de Valera refused to punish individual opponents, such as Joseph Nugent, it was challenged by many republicans; both within the IRA and Fianna Fáil, but the overwhelming majority of republicans had no other option than Fianna Fáil. The deep social, political, cultural and economic division within Irish society produced by the Civil War created such an environment that by 1932 even the most radical republican hesitated to criticize Fianna Fáil, fearing that to do so would be tantamount to giving aid and comfort to the enemy, that is, to Cumann na nGaedheal. This was evident in Kinnitty. During the agitation, the McGuinness brothers had warned Fianna Fáil that it would be punished by republicans for its failure to support Craven ${ }^{70}$. When a General Election arrived six months later in January 1933, their threats proved empty. In the constituency of Leix-Offaly, Fianna Fáil increased its share of polls by $3 \%$ and while TD Patrick Gorry failed to win reelection, another Fianna Fáil TD took his seat ${ }^{71}$.

While the McGuinness brothers and O'Donnell led demonstrations of a few hundred in Kinnitty, de Valera addressed a rally that numbered 30,000 in Dublin as the Economic War with Britain intensified ${ }^{72}$. As the republican base became increasing radicalized by the anti-British rhetoric, and as Fianna Fáil successfully framed a financial and tariff dispute as an "Economic War", Twomey saw an opportunity for the IRA to challenge Fianna Fáil's leadership in the new struggle with Britain. In the autumn of 1932, the IRA launched the Boycott British League which attempted to convince people in Ireland to stop purchasing British made goods. When this failed - apparently people in Ireland actually liked some British goods - the League attempted to enforce the boycott which quickly degenerated into a series of stunts as IRA units traveled the country smashing bottles of Bass Ale and boxes of Cadbury Chocolates. Such campaigns, of course, could not rebuild the revolutionary republican movement nor challenge Fianna Fáil for the hearts and minds of the republican base. Unlike the agrarian agitation of the Kinnitty eviction, however, the Boycott British League did assist Twomey in his main goal of maintaining Army unity as it was supported by both the social republicans and the militarists; indeed, both Sean McGuinness and Tom Barry eagerly joined the campaign.

69. J. Peter Neary and Cormac O’Grada, “Protectionism, Economic War, and Structural Change: the 1930s in Ireland”, Irish Historical Studies XXVII, n 107 (May 1991), p. 250.

70. Irish Times, 23 July 1932, p. 7.

71. Irish Press, 27 January 1933, p. 1.

72. Ibid., 29 July 1932, p. 1. 
In September 1932, George Gilmore, perhaps the deepest thinker among the social republicans within the IRA leadership, wrote to Twomey:

I do not agree with Peadar O'Donnell in his belief that there is a revolutionary situation in the country only waiting for someone to assume leadership. On the contrary, I believe that particularly all the republican and anti Free State feeling in the country is hopelessly pro-Dev., and that Fianna Fail are going to hold the field for a very long time to come, and I do not see how anything we could have done for the past 6 months would have altered that ${ }^{73}$.

Gilmore's analysis proved prophetic, although one suspects that Gilmore did not imagine that Fianna Fáil would remain Ireland's largest political party for nearly 80 years. Fianna Fáil's ascension to state power presented the IRA leadership with a problem for which it never found an answer; perhaps it never really understood the question, perhaps there was no answer as Gilmore suggested. Twomey and others within the IRA wondered if their hatred of the "Cosgrave Murder Gang" would lead to their demise at the hands of Fianna Fáil: "Some of us have a feeling that Fianna Fáil know we are so much opposed to the late Imperial gang that we would go a long way to end their power for all time. They wonder could they exploit that opposition to the point of abolishing ourselves ${ }^{74}$ !" The evidence suggests yes. Their mutual defeat in Civil War and the resulting deep mutual hated of the Cosgrave regime and its supporters had bound all republicans together. From Fianna Fáil's formation in 1926 to its ascension to state power in 1932, most republicans saw no inconsistency in supporting both the IRA and Fianna Fáil. Once in power, of course, the former "slightly constitutional party" became fully constitutional and republicans, such as those in Kinnitty, were now forced to choose between the IRA and its revolutionary republicanism or Fianna Fáil's constitutional republicanism, which was now sweetened with the material and psychological rewards of state power, that is, a republicanism that could cut your land annuity payments in half and control the Land Commission's distribution of land. Subsequent election results suggest that for the overwhelming majority of republicans this was not a difficult choice.

73. Letter from George Gilmore to Chairman, Army Council [IRA], 16 September 1932, UCDA P69/53/368.

74. Unsigned letter from [IRA Army Council] to Brother [Joseph] McGarrity, 25 August 1932, UCDA P69/185/217. 